\title{
INTEGRATION OF HANDHELD GUIDES IN MUSEUMS: THE CASE OF LITHUANIA'S ART MUSEUMS
}

\begin{abstract}
Summary. The most common technological device found in organisations of cultural heritage is a handheld guide. This device can simultaneously perform several functions, and its integration in permanent expositions has significance both for the operation of organisations of cultural heritage and experience of visitors when they visit a museum or a gallery. It should be noted that art museums and galleries encounter a task to present often static and difficult to understand at first sight works of art in an interesting fashion. Therefore, in this study, the main functions of a handheld guide as a technological device as well as its benefits, problems, and application in art museums are analysed.
\end{abstract}

In the first part of the study, various functions of handheld guides, their importance, the meaning produced for the organisation of cultural heritage, and experience of a visitor are analysed based on scientific literature. Problems of integration of handheld guides and strategic steps that should be taken to ensure a successful integration process are reviewed. In the second part, four cases of Lithuanian art museums are presented. All museums that participated in the survey were analysed by collecting observational data, communicating with the managers of the organisations, and analysing the experience of museum visitors using the handheld guide.

Scientific literature presented in the article substantiates the importance of handheld guides in museums and possible problems of integration of such devices. The study conducted in Lithuanian art museums reveals the fact that handheld guides are significant devices that help improve the experience of a museum visitor, but it is also observed that handheld guides have not yet become an integral part of a visit to a Lithuanian art museum.

Keywords: museum, art museum, handheld guide, permanent exhibition, integration, experience of a visitor, information presentation, content of a handheld guide, appearance of a handheld guide.

\section{INTRODUCTION}

Museum computerisation that started in the 20 th century has already had a great influence on the way museums operate. In the beginning of the computerisation process, devices developed using new technologies were used to make internal work of employees faster and more efficient. Later, when the internet and new technologies invaded the everyday life, museum visitors started to expect a unique experience. The aim to remain actual and attractive to visitors encouraged museums to use technological devices not just for improvement of internal work but also to communicate with the visitors, to present the expositions in an original way, and to provide additional information. ${ }^{1}$ Therefore, starting with the mid-20th century, museum visitors acquired the possibility to use technological devices that aimed and are still aiming to improve the experience of visiting a museum. ${ }^{2}$

The most common technological device found in museums is a handheld guide. It is a portable video or audio player that contains recordings related to the museum exposition and exhibits in it. The said technological device usually has several goals: context providing, expansion of audience, personalisation of a visitor's experience, and saving human resources. ${ }^{3}$ Handheld guides are often considered to be integral parts of museum expositions. They started to be used in the middle of the 20th century, whereas in Lithuania active integration of such devices has been observed in the early 21 st century.

The subject of the present study is the integration of handheld guides, the need for them, and their importance to a visitor of Lithuanian art museums. 
- The subject was chosen because of its relevance after evaluating the following: enhancement of new technologies' adaptation in museums, high demand for handheld guides, polysemy of functions of said guides, and specifics of art museums and galleries. The fact that no studies have so far been performed in Lithuania that analyse the integration of handheld guides in Lithuanian art museums and the impact of handheld guides on the visitor experience has also influenced the selection of the subject.

Major Lithuanian art museums have been selected as subjects of the study: the Lithuanian Art Museum (hereinafter LAM), the M. K. Čiurlionis National Museum of Art (hereinafter NČAM), ${ }^{4}$ and $\mathrm{MO}$ Museum.

The objective of this study is to investigate the integration of handheld guides in permanent expositions of major Lithuanian art museums and its influence on the activity of the museums and the experience of visitors.

The article consists of two parts. The first part is dedicated to the subject of the handheld guide integration in museums based on scientific literature. The article is based on the research of Jorgen Riber Christensen, Esther Dijk, Žilvinè GaižutytèFilipavičienè, Meisert Anke, Alexandra Schautz, Ross Parry, Loick Tallon, Kevin Walker and Andrea Witcomb, and others.

In the second part of the article, the implemented empirical study is described. Study data that were gathered visiting museums, interviewing representatives of museums, and conducting focus groups at LAM, NČAM, and MO Museum are presented and analysed.

\section{MAIN FUNCTIONS OF HANDHELD GUIDES}

Despite the early introduction of handheld guides in museum expositions, the main functions of handheld guides remain the same, and the demand for their use has not decreased so far. The popularity of the said guides is validated by statistics: handheld guides are integrated in more than a half of all art museums in the world, and these devices are used more than 35 million times a year. ${ }^{5}$ One can often see a group of museum visitors to whom a guide is presenting the exposition. In this case, a group is obliged to listen to a narrative of one person and follow the pace and route dictated by this person. Participation in such a group tour may influence the unfulfilled individual expectations of a visitor. The handheld guide helps reduce such threat as it provides an opportunity to each visitor to personalise his or her visit to the museum. ${ }^{6}$ The visitor using a handheld guide can choose the individual speed of the visit, he or she also has the opportunity to select about which exhibits more information is desirable. Museums should provide their visitors with opportunities for creation of individual experiences and propose tools that would help achieve this. ${ }^{7}$ In this case, a handheld guide is one such tool.

Context creation is another function performed by a handheld guide. Quite often, museums are visited by visitors who do not have up-front or deep knowledge about the presented exposition. Labels that accompany exhibits and present general information about the artwork (author, title, year of creation, place) are often insufficient to understand the exhibition well.

To solve this problem, museums use handheld guides. Audio recordings on these devices present to a visitor both general information about the museum and its exposition and major facts about specific exhibits. For example, a study of visitor experience was conducted after modified handheld guides had been integrated in the Metropolitan Museum of Art. $^{8}$ Among the questions presented to the visitors, one asked what information in the handheld guide they considered the most important. The biggest group of participants ( 181 persons) responded that, to them, historical context was the most important. The second by relevance of information to the visitors were insights that help understand the exhibited artwork and the essence of its content. The study performed by the Metropolitan Museum of Art proves the significance of the function of context creation.

The aspect of saving human resources is also worth mentioning. It is difficult to envision a museum audience without foreign tourists. A person who does not communicate in the local language could frequently 
be encountered in a museum. In a handheld guide, information about the museum and its exhibits can be presented in various foreign languages. ${ }^{9}$ The multiple language function does not oblige museums to hire guides that would have high-level knowledge of various foreign languages. Thus financial and human resources of a museum are saved, while its visitors have the opportunity to assimilate the information more easily while listening to it in the languages that they understand the best.

Museums that want to attract and maintain different groups of visitors have to provide high-quality accessibility to information for individuals of different cultures and abilities. ${ }^{10}$ Handheld guides are useful to museums not just by saving human resources but also by expanding audiences. From the very beginning of the integration of handheld guides, one of their major functions was to increase the visitor audience. ${ }^{11}$ The earlier-mentioned multilingual function adds to the attractiveness of a museum for international audiences. Moreover, when it comes to handheld guides and expanding audiences, it is important to pay attention to visitors with disabilities. Quite often a presentation of an exposition is implemented in sign language. Thus comprehensive information about the exhibits of a museum becomes available to visitors with hearing impairment. Visitors with vision impairment are presented with audio recordings that describe the exhibits particularly clearly and thoroughly and provide information about the museum's infrastructure (e.g., how many steps are ahead) that helps people with vision impairment orientate in the physical space of the museum.

Right now, greater attention towards museum visitors with disabilities is supported by real-life examples and implemented projects. One such example is the activity of the New York Hall of Science. ${ }^{12}$ Approximately in 2000, this museum developed handheld guides for individuals with vision impairment. The content of the devices was developed bearing in mind that audio recordings for blind people must be more thorough and vivid than those intended for the rest. When the devices were integrated, each visitor with vision impairment had an opportunity to choose how he or she wanted to see the exposition: with a handheld guide or with an accompanying person. A later study revealed that such visitors chose handheld guides more often. They explained their choice by their desire to see the exposition independently and by the fact that a handheld guide often presents exhibits in a clearer way than an accompanying person would. This case is one of the examples how handheld guides create better experience for visitors with disabilities and contribute to expansion of audiences.

Coordination of a visitor is another function performed by a handheld guide. By audio recordings, a museum can control a visitor both when they are moving in the museum space in general and when they are looking at a specific exhibit. When listening to a handheld guide, a visitor can hear advice how, for example, a painting should be viewed. Audio recordings can specify the distance from which the artwork should be observed, the angle at which it is advisable to look at the artwork, and the important details to which one should pay attention to better understand the content of the artwork, its form, and imparted thought. ${ }^{13}$

Apart from the already reviewed functions of handheld guides and their benefits, it is worthwhile to discuss the extended visitor experience. Various studies have revealed that a visitor using a handheld guide enjoys their visit to a museum more, and this has an impact on the duration of the visit. This happens mostly because a handheld guide encourages a visitor to stop at specific objects and to spend more time viewing and analysing them. While a visitor explores the exhibit, a handheld guide emphasises its uniqueness and details which would have otherwise been overlooked. It is maintained that a handheld guide extends a visit by approximately 60 percent. ${ }^{14}$

Handheld guides may also present games related to expositions. Museums are motivated to guarantee the highest possible level of education. In pursuing this objective, it is worthwhile to notice that people remember 20 percent of what they have heard; 40 percent of what they have heard and seen; and 75 percent of what they have heard, seen, and done. The following quotation illustrates these percentages 
well: "What I hear I forget; what I see I remember; what I do I understand." 15 A handheld guide is a means that can combine all three elements, therefore it can be considered a useful tool of education in museums. The new technologies enable handheld devices to present not just audio but also video material and educational games to visitors. Although the game function in museums is quite often performed by interactive terminals, a personal mobile device is more attractive to children because of their habit of using mobile phones. ${ }^{16}$

In summary, the main functions of handheld guides are: context creation, saving human resources, expansion of audiences, personalisation and extension of museum visits, education, movement direction, and enrichment of experience. Handheld guides allow museums to provide higher quality visits. However, it should be taken into account that quality integration requires adequate preparation and knowledge of the device user audience. The threats and most important steps of handheld guide integration are reviewed in the following part of the article.

\section{PROBLEMS OF HANDHELD GUIDE INTEGRATION}

First of all, it should be understood that museum audiences are not homogeneous. Behaviour of a person visiting a museum is determined by his or her prior experience, knowledge, available perception, and expectations. ${ }^{17}$ For example, content of a handheld guide that contains a lot of language characteristic of culture and art professionals is not acceptable to visitors who do not have specialised art knowledge. For this reason, in the beginning of device integration, it is particularly important to precisely define the audience of handheld guide users and to understand their habits and relation to the new technologies and, based on these data, to develop a handheld guide that would meet their interests. Developing a "universal" handheld guide may not only negatively impact visitors' experience at the museum but also reduce their motivation to use such devices when visiting other museums.

Development of handheld guides for children requires special creativity. Handheld guides for younger audiences must look attractive, because young people use new technologies in their everyday life. ${ }^{18}$ However, content of a handheld guide is as important as its appearance. When introducing children to art, it is important to maintain a conversation and a discussion about art with them to arouse their personal interest or talent. ${ }^{19}$ The handheld guide integrated at the Nationalmuseum in Stockholm, in which the exposition is presented to children by a selected animal character, may be considered a successful example of a handheld guide for children. Children using the guide can choose both the character and the complexity of its speech. The character helps maintain a child's attention during the entire visit, while the selection of speech complexity makes the handheld guide suitable for children of different ages.

Museum employees should be well acquainted with operation and content of handheld guides. It is important that, prior to their visit, a visitor would be well informed by the museum employees on how to use the device. ${ }^{20}$ Providing information should be smooth, clear, and fast. Otherwise, museum employees risk not only negatively impacting the experience of a visitor from the very beginning but also facing rapidly growing queues.

Having in mind that a handheld guide often becomes a companion of the visitor for the entire visit, it is important that the device would be handy both in shape and use. If navigating a handheld guide requires a lot of effort or time, it is likely that the person using the guide will dedicate more time to the device than to the exposition, for the better knowledge of which the handheld guide is intended. It is also worth noticing that each handheld guide should have easily obtainable information on the principles of its control. ${ }^{21}$ This function is necessary to let the visitor always find answers about the navigation of the handheld guide without additional assistance.

People often visit museums as members of a group. One of the main goals of people who visit a museum with a company is to have quality time together. ${ }^{22}$ However, according to studies, visitors seldom spend a lot of time communicating with others 
during their visit to the museum, but it is nevertheless important that a handheld guide would not constrict the opportunity to socialise. ${ }^{23}$ It is advisable to adjust the interactive devices to both individual and group visits.

To summarise the information presented in this part of the article, handheld guides are useful but may also cause negative experiences for museum visitors. When integrating handheld guides in museums, it is necessary to consider the purpose for which the handheld guide is being developed. When the target audience of the device is defined, it is important to pay attention to the hobbies of the audience, its likely knowledge about the exposition, and its habits of using new technologies.

\section{STRATEGY OF HANDHELD GUIDE INTEGRATION}

Having in mind that new technologies are constantly becoming cheaper, faster, and easier to control, it is likely that, in the future, interactivity based on new technologies will increase, therefore, it is important to review the aspects that have to be taken into account prior to the process of handheld guide adaptation for museum expositions.

In the beginning of device integration, it makes sense to review the up-to-date success of its implementation and future perspectives. These insights are necessary for the museum to understand whether the suggested idea of the device conforms to the museum's mission and goals. ${ }^{24}$

In the next part of the integration, it is important to define the audience for which the device is intended, to understand the exact reasons that started the integration of the device, and to foresee the final outcome and the way to understand whether the integration of the device has produced the desired outcome. This way, the real benefit of the project both for the museum and its visitors is evaluated. In this phase, it is expedient to review similar device integrations implemented in other museums. This helps foresee possible threats and ways to reduce them. ${ }^{25}$

Later, it is important to clarify the organisation's capability of implementing the project. In this phase, it is advisable to start a systemic documentation of the project. Such analysis helps understand what the organisation already has and what needs to be acquired to turn the idea into a real project or service. In this phase, it is important to proceed with particular rationality and honesty to maximally reduce possible risk factors. ${ }^{26}$

After having performed self-analysis, it is recommended to elaborate the design and content of the device. In this part of the integration, it is worth to notice that: there is no technological device that would be applicable to all sorts of audiences; the control of handheld guides should resemble the control of devices that visitors use in their everyday life; visitors have to clearly understand that they are controlling the device; information presented in the handheld guide must clearly correlate with the museum and the exposition; visitors appreciate more the content that is presented in everyday rather than professional language; the handheld guide should not interfere with the communication with other visitors; the control of the device should be fast, clear, and simple; before presenting the handheld guide to visitors, it is advisable to test it with representatives of the target user group. ${ }^{27}$

Integration of handheld guides may be a challenge, but it depends on the audience who actively researches and develops the cultural heritage field with what means and how fast this challenge will be converted into a beneficial process.

\section{CASE STUDY OF LITHUANIAN ART MUSEUMS}

In this study, case study methodological strategy has been used. Qualitative study methods have been selected: content analysis, participant observation, semi-structured interviews, and focus groups. Handheld guide content analysis was started in late 2018: in October, in the National Art Gallery and at the Vytautas Kasiulis Art Museum, and in December, at MO Museum. In March 2019, content analysis was carried out in the M. K. Čiurlionis Art Gallery of NČAM and, considering the changed exhibition, a repeated content analysis was carried out at MO Museum. During the content analysis (October 2018-March 2019), eight semi-structured interviews 
were conducted: with MO Museum curator Migle Survilaite, Head of the Lithuanian Museums' Centre for Information, Digitisation, and the Lithuanian Integral Museum Information System (hereinafter the LIMIS Centre) Danute Mukienè, ${ }^{28}$ acting manager of the Palanga Amber Museum of LAM Regina Makauskiene, senior curator of the Clock and Watch Museum of LAM Giedrūda Kazonienè, division manager of the Pranas Domšaitis Gallery of LAM Kristina Jokubavičiene, excursion division manager of the Vytautas Kasiulis Art Museum of LAM Juste Janulevičiūte, ${ }^{29}$ representative of the National Art Gallery of LAM Giedrius Gulbinas, curator of the M. K. Čiurlionis division of NČAM Julija Račiūnaite, and manager of the M. K. Čiurlionis division of NČAM Vaiva Laukaitienè. Following the content analysis and semi-structured interviews, an analysis of visitor experience was conducted in March-April 2019, applying the pilot/experimental focus group method ${ }^{30}$ at the Palanga Amber Museum, ${ }^{31}$ the M. K. Čiurlionis Art Gallery, the National Art Gallery, and MO Museum. Representatives of different age groups and professions with different levels of cultural and artistic knowledge participated in the focus groups. The number of participants in each focus group varied from 6 to 8 and their age varied from 19 to $73 .{ }^{32}$ Thus, the main priority was to gather as much data as possible, revealing different experiences of using handheld guides.

\section{PROCESS OF HANDHELD GUIDE INTEGRATION}

In this section, the process of integration of handheld guides in Lithuanian art museums is presented based on the data from the interviews with museum employees.

Objectives of integration. When analysing the objectives of the handheld guide integration in Lithuanian art museums, common causes that encouraged museums to introduce handheld guides into expositions emerged. All museums perceived adaptation of the devices as a necessary process. Handheld guides at the Palanga Amber Museum were integrated as part of the process of museum modernisation and to expand the spectrum of services provided to the visitors. In the case of the National Art
Gallery, handheld guides were integrated to expand educational opportunities. MO Museum integrated the handheld guides to make the objects of art as available as possible to the target visitor audience. In the M. K. Čiurlionis Art Gallery, handheld guides appeared because of the previously mentioned reasons and the wish to save human resources.

Integration process. Integration of handheld guides in museums was conducted in different ways. The project implemented by the LIMIS Centre had a significant influence on the appearance of handheld guides at the Palanga Amber Museum. During the project, the devices were developed for some divisions of LAM. When the museum found out about the project, it prepared content for the device in Lithuanian. The LIMIS Centre took care of the translation into foreign languages, audio recording, and the model of the device. When the museum approved the recording and the translation, devices from the LIMIS Centre were delivered to the museum.

Integration of handheld guides in the National Art Gallery started unexpectedly. A decade ago, an event on information technologies took place in the gallery, during which the participants had to develop a virtual application. One of the participating teams took into consideration the fact that the event took place at the Lithuanian Art Museum and proposed to develop the initial application for a handheld guide. Employees of the gallery agreed and were satisfied with the developed initial version of the application, so they decided to implement the project in full continuous cooperation with the team. The National Art Gallery took care of the content development, translation, and audio recording, while the team that participated in the event developed the technological base of the handheld guide.

Representatives of MO Museum took care of the handheld guide by themselves by following successful foreign examples, communicating with the experts of the field, and using the knowledge acquired while participating in various conferences. Experts of corresponding areas-writers, art critics, journalists, and employees of radio stations-took care of the text creation. 
Integration of handheld guides in the M. K. Čiurlionis Art Gallery was encouraged by the Audiogidas company. Audiogidas offered to prepare a project for obtaining funding and later took care of the technological development of the handheld guide and contributed to the preparation of content and audio recording.

Problems of integration. When reviewing the most complicated parts of the handheld guide application, it should be noted that the M. K. Čiurlionis Art Gallery was the only one that did not encounter any difficulties. Based on the interview, this was thanks to the professional work of Audiogidas. At present, however, the gallery encounters the problem of the technological wear of handheld guides, which was named as the biggest problem. Other subjects of the study named content development as the most difficult part of integration. The most complicated part was selecting the exhibits and creating audio recordings that would be informative and attractive to visitors. Despite the encountered difficulties, the study shows that representatives of all museums that participated in the study are happy with the integration of handheld guides, which has met their expectations.

Testing, supply, and demand of handheld guides. MO Museum was the only one to test their handheld guide with the target user audience before presenting it to all users. In the case of other museums and galleries, handheld guides were tested by employees themselves. As for the supply and demand of the devices, it has been observed that the biggest demand of handheld guides is at MO Museum and the Palanga Amber Museum. It is likely that this is influenced by active employees of the museum booking offices who inform visitors about the device. The demand for handheld guides in the $\mathrm{M}$. K. Čiurlionis Art gallery increased when its content was translated into additional languages (not just English). The lowest demand for the devices is in the National Art Gallery, but the study data show that the cashiers at the gallery are the least interested to present handheld guides to the visitors. Subsequent analysis of visitor experience revealed that devices being presented by museum employees are often the key factor that motivates the visitors to use them.
Future objectives of expanding handheld guide integration. When it comes to further perspectives of handheld guide integration, it has been observed that the Palanga Amber Museum has set a goal of creating a handheld guide for children. The development of such device is intended to be done in cooperation with the LIMIS Centre. This was confirmed by a representative of the LIMIS Centre. Other subjects of the study did not have specific handheld guide integration development plans. The National Art Gallery intends to renew the devices after changes in the permanent exposition, but so far this idea is not given too much attention. MO Museum would like to develop a handheld guide for younger visitors (contentwise) in the future, while the M. K. Čiurlionis Art Gallery prioritises a technological upgrade of the device. However, as is also the case with the National Art Gallery, currently these are abstract ideas that are to be specified some time in the future.

\section{OBSERVATIONAL DATA AND ANALYSIS OF VISITOR EXPERIENCE}

Forms of devices for handheld guides. While visiting the subjects of the study, various types of devices have been observed. At the Palanga Amber Museum, the handheld guide is presented in a tablet, in the National Art Gallery-in an iPod audio and video player, in the M. K. Čiurlionis Art Gallery-in a small audio player without a screen, and at MO Museum, to hear the guide one must use a personal smart device. Based on the observational data, handheld guides at MO Museum and the National Art Gallery were appreciated as the most convenient. The handheld guide at the Palanga Amber Museum, despite its easy controls, was too heavy for a handheld guide. The handheld guide in the M. K. Čiurlionis Art Gallery lacked technological novelty and did not have a screen. Visitor experience analysis revealed similar results. According to the study data, the screen of the Palanga Amber Museum handheld guide is too big. However, it could have been appreciated if more features on the screen had been used. Visitor experience analysis revealed that holding a guide of such weight during the entire visit is not convenient and may cause 
arm pain. Visitors of the M. K. Čiurlionis Art Gallery have noticed the lack of screen in the handheld guide. The study shows that visitors tend to favour handheld guides that are not technologically outdated. The handheld guide of MO Museum was rated positively, and using a personal smart device did not cause any problems to the participants of the study. On the other hand, it has been observed that such form may be inconvenient to visitors of older age or foreign guests. Despite technological flaws and reduced sensitivity of its touch screen, the handheld guide of the National Art Gallery was rated favourably because of its technological novelty and ease of control.

Content of handheld guides. Observational data reveal that content of handheld guides of the Palanga Amber Museum and the National Art Gallery is distinguished by abundance of information and use of professional language. In the case of the former museum, the handheld guide contains a lot of audio recordings, and the voice of the presenter is monotonous, therefore it is difficult to maintain attention in the second half of the visit. The handheld guide of the National Art Gallery is briefer but contains plenty of art criticism terms that may cause discomfort to a visitor who is less familiar with Lithuanian art. Data of the visitor experience analysis confirm this information. Significant amounts of academic content have been observed in the audio recordings of the handheld guide of the National Art Gallery, while the content of the one at the Palanga Amber Museum was criticised because of abundance of information and lack of interesting details. The content of the MO Museum handheld guide was deemed one of the best. This was determined by the limited number of audio recordings (around twenty-four), their optimal duration (around a minute each), and limited use of academic and professional language. For a researcher, its content sometimes seemed to be overly simplified, but prior knowledge might have had influenced such impression. Participants of the visitor experience study particularly appreciated the style of the language used in this guide. The content of the M. K. Čiurlionis Art Gallery handheld guide is presented in an original way-by using personages and supplementing their stories with musical background (from Čiurlionis' works). Because of that, both observational and visitor experience study data show that it was interesting to listen to the content and there was no desire to skip the audio recordings. During the observation, a lack of balance in the use of language was observed. In some recordings, many terms of art criticism can be heard, while in others everything is presented in simple, everyday speech. However, only a few visitors noticed that, while other participants of the study were satisfied with the presentation. This handheld guide may be viewed as an example of how the content of a handheld guide is more important than its appearance.

Functions of devices. In the study, handheld guide functions that were appreciated the most by the visitors were analysed. Observational and visitor experience analysis data both show that visitors appreciate devices based on their capability to create individual experiences. None of the handheld guides reviewed in the study oblige the visitor to listen to the recordings coherently. Each individual, based on his or her personal expectations, can choose audio recordings that are interesting to him or her but is not obliged to follow the visit pace dictated by the guide. Context creation is another distinguished function of the devices. The survey of visitor experience shows that the participants felt a greater interest in an exposition and understood the exhibited artwork better with a handheld guide. The study has revealed the importance of direction indication in audio recordings. The strongest lack of such indications was observed in the handheld guide of $\mathrm{MO}$ Museum. This was influenced by the unclear structure of the exposition. The study shows that, when the total number of exhibits is great, it is important to inform the visitors on how to find a specific object presented in the handheld guide. Such references were found only in the handheld guide of the M. K. Čiurlionis Art Gallery. Despite the fact that, according to the observational data, the references seem to be excessively detailed, participants of the visitor experience survey appreciated them nevertheless. The participants also noted the general map of the National Art Gallery which was incorporated into its handheld guide. The participants of 
the survey did not use the map, as the infrastructure of the National Art Gallery is not misleading and it is not complicated to pass from one exhibition hall to another. However, according to the data of the study, it may be maintained that such maps should be included in all handheld guides.

Use of handheld guides. As mentioned earlier, the study has revealed that visitors of museums rate the use of handheld guides positively and regard them as necessary, despite the fact that a major part of the participants of this study had not previously used handheld guides in museums. During the analysis, it also became clear that the visitors have not yet formed a habit of using such devices. Quite often, the device is not used not because of lack of motivation but because of lack of knowledge about such possibility. The study data show that visitors would use handheld guides more often if museum employees informed them about that at the beginning of their visits. This data substantiate the importance of information provided by the museum employees for the demand for handheld guides.

\section{CONCLUSIONS}

Handheld guides have been introduced into all major Lithuanian art museums, but their integration is implemented only in a small portion of the permanent expositions of these museums. LAM has nine divisions, but handheld guide integration has been implemented only in five of them. It is important to mention that, out of the five divisions, only in three visitors are actively offered the opportunity to use handheld guides (the National Art Gallery is not actively offering them, while at the Vytautas Kasiulis Museum, the offering has been suspended due to the wear of the devices). Out of eleven operating divisions of NČAM, only two-the Mykolas Žilinskas Art Gallery and the M. K. Čiurlionis Art Gallery-have handheld guides suitable for their expositions, but devices in the Mykolas Žilinskas Art Gallery are currently not operational, therefore handheld guides may be used only in one division of NČAM-the M. K. Čiurlionis Art Gallery. According to observational and visitor experience study data, it is safe to say that, as of today, handheld guides have not yet become an integral part of visits to Lithuanian art museums.

In major Lithuanian art museums, just like in foreign museums, the integration of handheld guides in expositions was determined by: the desire to be progressive and increase the spectrum of services offered to visitors, the aim to provide visitors with informative narratives about the exhibits and their context, and the possibilities to save human resources and expand audiences. The results of the study show that handheld guides and demand for them meet the expectations of museums and galleries.

The LIMIS Centre took care of the handheld guide integration in all divisions of LAM except the National Art Gallery. The National Art Gallery, M. K. Čiurlionis National Museum of Art, and MO Museum took care of the integration of handheld guides independently and cooperated with text developers, presenters, and IT experts. The Audiogidas company assisted the M. K. Čiurlionis National Museum of Art in the entire process of the device integration. Despite different ways of handheld guide integration, the study confirms the statement found in scientific literature that the most complicated part of integrations is developing the content that would be interesting to the visitor, which requires significant time resources and good understanding of the target audience of handheld guide users.

Context creation and personalisation of visitsaccording to the study data-are the handheld guide functions that are appreciated by visitors the most. Visitors consider a visit to a museum with a handheld guide to be more interesting because of the wider information about the exposition and the exhibits found in the guide. The usefulness of the device is substantiated by the visitors' satisfaction with the possibility to create an individual experience. A handheld guide has been appreciated as a device which meets visitor expectations better than a group excursion in which a big group of people is coordinated by one guide.

Directions, helping a visitor orientate in the physical space of a museum or a gallery, are an important element of the handheld guide content. Of 
all museums and galleries that participated in the study, only the handheld guide of the M. K. Čiurlionis Art Gallery informs the visitor in which direction to continue to reach the next exhibit presented by the device. The lack of directions was felt the most in the content of the MO Museum handheld guide. According to the collected study data, this was caused by the unclear infrastructure of the museum. It was difficult for visitors to absorb all the information about the artworks presented by the handheld guide at the Palanga Amber Museum because of the abundance of exhibits. The lack of this function was felt the least at the National Art Gallery. The study data show that this was caused by effective arrangement of the exhibits presented by the handheld guide.

Major Lithuanian art museums present handheld guides of various types and ways of content presentation. In the M. K. Čiurlionis Art gallery, the most technologically outdated device, compared to the other museums, is used. At the Palanga Amber Museum, the content of the handheld guide is presented in modern devices broadcasting both sound and image. To hear the content of the handheld guide of MO Museum, a personal smart device must be used. The study data have revealed that the design of a handheld guide impacts the overall experience of a visitor. Devices that are more technologically advanced are preferred over the technologically outdated ones, while the use of a personal device is considered an obstacle.

The context presented in a handheld guide has a greater impact on visitor experience at a museum than its appearance. This is confirmed by the data received from representatives of museums and galleries as well as from participants of the visitor experience analysis. Despite the technological wear, the handheld guide of the M. K. Čiurlionis Art Gallery (division of NČAM) was among the most favourably rated. The content of this guide and its presentation was appreciated as interesting, not monotonous, and creative. The example of the handheld guide of the M. K. Čiurlionis Art Gallery reveals that not the model but amount of presented information and an uncomplicated, original way of its presentation have a greater impact on the visitor experience.

\section{References}

Christensen, Jorgen Riber. "Four steps in the history of museum technologies and visitors' digital participation." Journal of media and communication research 50 (2011): 7-29.

Gaižutyte-Filipavičienė, Žilvinè. "Meno muziejai ir medijos." In Lietuvos kultūros tyrimai 2: Muziejai, paveldas, vertybès, edited by Rita Repšienè. Vilnius: Lietuvos kultūros tyrimų institutas, 2012. 47-63.

Goodwin, Hannah. "American Sign Language and Audio Description on the Mobile Guide at the Museum of Fine Arts, Boston." Curator: The Museum Journal No: 56 (2013): 369-370.

Kardelis, Kęstutis. Moksliniu tyrimu metodologija ir metodai. Vilnius: Valstybès įmonè Registrų centras, 2016.

Parry, Ross. Museums in a Digital Age. London: Routledge, 2012.

Schautz, Alexandra, Esther Dijk, and Meisert Anke. “The Use of Audio guides to Collect Individualized Timing and Tracking Data in a Science Center Exhibition." Visitor Studies 19 (2016): 96-116.

Tallon, Loic, and Kevin Walker. Digital Technologies and the Museum Experience: Handheld Guides and Other Media. Lanham: Rowman Altamira, 2008.

\section{Notes}

1 Ross Parry, Museums in a Digital Age (London: Routledge, 2012), 27.

2 Loic Tallon and Kevin Walker, Digital Technologies and the Museum Experience: Handheld Guides and Other Media (Lanham: Rowman Altamira, 2008), 7.

3 Žilvinè Gaižutytė-Filipavičiene, "Meno muziejai ir medijos" in Lietuvos kultüros tyrimai 2: Muziejai, paveldas, vertybès, ed. Rita Repšienè (Vilnius: Lietuvos kultūros tyrimų institutas, 2012), 57.

4 LAM has nine subdivisions: the Vilnius Art Gallery, the National Art Gallery, the Clock and Watch Museum, the Radvilos Palace, the Vytautas Kasiulis Art Museum, the Pranas Domšaitis Gallery, the Palanga Amber Museum, the Museum of Applied Arts and Design, and the Museum of Miniature Art.

NČAM has eleven active subdivisions: M. K. Čiurlionis National Museum of Art, the Mykolas Žilinskas Art Gallery, the Kaunas Picture Gallery, the Žmuidzinavičius Creations and Collections Museum, the Devils' Museum, the Historical Presidential Palace of the Republic of Lithuania, the A. and P. Galaune House, the L. Truikys and M. Rakauskaite Memorial Museum, the Juozas Zikaras Memorial Museum, the V. K. Jonynas Gallery, and the M. K. Čiurlionis Memorial Museum. NČAM has one currently inactive subsidiary-the Ceramics Museum.

5 Tallon and Walker, 57.

6 Gaižutytè-Filipavičienè, 57.

7 Tallon and Walker, 115.

8 Ibid., 67.

9 Hannah Goodwin, "American Sign Language and Audio Description on the Mobile Guide at the Museum of Fine Arts, Boston," Curator the Museum Journal 56 (2013): 369.

10 Tallon and Walker, 97.

11 Ibid., 98.

12 Ibid., 101. 
13 Jorgen Riber Christensen, "Four Steps in the History of Museum Technologies and Visitors' Digital Participation," Journal of Media and Communication Research 50 (2011): 20 .

14 Alexandra Schautz, Esther Dijk, and Anke Meisert, "The Use of Audio Guides to Collect Individualized Timing and Tracking Data in a Science Center Exhibition," Visitor Studies 19 (2016): 133.

15 Parry, 24.

16 Tallon and Walker, 124.

17 Ibid., 41.

18 Ibid., 142.

19 Ibid., 168

$20 \quad$ Ibid., 87.

21 Ibid., 43.

22 Ibid., 47.

23 Ibid., 66.

24 Parry, 356

25 Ibid., 359.

26 Ibid., 361.

27 Tallon and Walker, 52.

28 In the process of the study, it emerged that, during the integration of handheld guides in divisions of LAM, the project implemented in the LIMIS Centre had a big influence, therefore, to obtain quality results, a representative of the LIMIS Centre was interviewed.

29 During the content analysis and semi-structured interviews, it emerged that handheld guides are not currently presented to the visitors of the Vytautas Kasiulis Museum due to their technological wear and required renewal of content. For this reason, the study of this museum was discontinued.

30 Kęstutis Kardelis, Moksliniu tyrimu metodologija ir metodai (Vilnius: Valstybès įmonè Registrų centras, 2016), 166

31 Taking into account that handheld guides ant their integration level at the Palanga Amber Museum, the Clock and Watch Museum, and the Pranas Domšaitis Gallery are very similar, the focus group was implemented only at the Palanga Amber Museum.

32 The exact number of focus group participants at each museum or gallery: the National Art Gallery-6, the Palanga Amber Museum-7, the M. K. Čiurlionis Art Gallery-7, MO Museum-8. It is important to note that the number of available handheld guides had an impact on the number of participants in the focus group of the National Art Gallery: at the present moment, there is a total of six operational handheld guides available.

Milda RUTKAUSKAITE்

Vytauto Didžiojo universitetas, Kaunas, Lietuva

\section{AUDIOGIDŲ INTEGRACIJA MUZIEJUOSE: LIETUVOS MENO MUZIEJŲ ATVEJIS}

\section{Santrauka}

Kultūros paveldo organizacijose dažnai aptinkamas technologinis ịrenginys - audiogidas. Tai kelias skirtingas funkcijas tuo pačiu metu galintis atlikti įrenginys, kurio integracija nuolatinèse ekspozicijose turi reikšmès tiek kultūros paveldo organizacijų veiklai, tiek lankytojų patirčiai lankantis muziejuje, galerijoje. Verta pastebèti, kad meno muziejams, galerijoms kyla papildomas uždavinys - lankytojui įdomiai pateikti statiškus, neretai iš pirmo žvilgsnio sunkiai suprantamus meno kūrinius. Dèl šių priežasčių šiame tyrime gilinamasi ị audiogido kaip technologinio ịrenginio pagrindines funkcijas, jo teikiamą naudą, problematiką ir pritaikymą meno muziejuose.

Pirmojoje tyrimo dalyje, remiantis moksline literatūra, analizuojamos skirtingos audiogidų funkcijos ir jų svarba, kuriama reikšmè kultūros paveldo organizacijai ir lankytojo patirčiai. Vèliau ap̌̌velgiama audiogidų integracijos problematika ir strateginiai žingsniai, kurių vertètų laikytis siekiant sèkmingo audiogido integracijos proceso. Antrojoje dalyje tiriami ir pristatomi keturi Lietuvos meno muziejų atvejai. Visi tyrime dalyvavę muziejai buvo analizuojami renkant stebejjimo duomenis, komunikuojant su organizacijų atstovais ir gilinantis ị lankytojų patirtị apsilankymo muziejuje metu naudojantis audiogidu.

Straipsnyje pristatoma mokslinè literatūra pagrindžia audiogidų svarbą muziejuose ir galimą šių įrenginių integracijos problematiką. Lietuvos meno muziejuose atliktas tyrimas atskleidžia, kad audiogidai yra reikšmingas ịrenginys siekiant pagerinti lankytojo apsilankymo muziejuje patirți, tačiau kartu pastebima, kad kol kas audiogidai nèra tape neatsiejama apsilankymo Lietuvos meno muziejuje dalimi. 
Reikšminiai žodžiai: muziejus, meno muziejus, audiogidas, nuolatinè ekspozicija, integracija, lankytojo patirtis, informacijos pateikimas, audiogido turinys, audiogido technologinè forma.

Gauta 2019-03-31

Parengta spaudai 2019-08-08

PhD student at the Faculty of Arts, Vytautas Magnus University, Kaunas, Lithuania

E-mail: milda.rutkauskaite@vdu.lt 